Article

\title{
Sustainable Development Goals in Early Childhood Education. Empowering Young Girls to Bridge the Gender Gap in Science
}

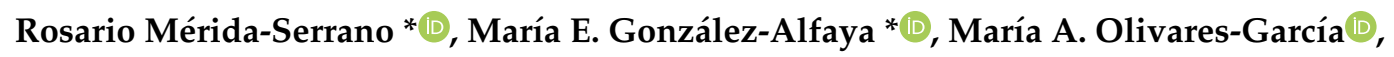 \\ Julia Rodríguez-Carrillo ${ }^{\circledR}$ and Miguel Muñoz-Moya \\ Department of Education, Faculty of Education Science, University of Córdoba, 14004 Córdoba, Spain; \\ ed1olgam@uco.es (M.A.O.-G.); m12rocaj@uco.es (J.R.-C.); p62mumom@uco.es (M.M.-M.) \\ * Correspondence: ed1meser@uco.es (R.M.-S.); ed2goalm@uco.es (M.E.G.-A.)
}

Received: 29 September 2020; Accepted: 5 November 2020; Published: 10 November 2020

\begin{abstract}
The present study is evaluative research on the program INFACIENCIA: From the girls of today to the women scientists of tomorrow. Its aim is to increase knowledge about relevant women scientists among the entire educational community and, specifically, to help children in gaining an inclusive image of science, i.e., one that values and shows female talent. The evaluation of this program is based upon qualitative research techniques, such as semi-structured interviews, in order to give voice to everyone involved. In this paper we focus on teachers' and families' perspectives. Findings show that when young children actively learn science, they develop positive attitudes towards it. At the same time, it is revealed how learning about women scientists boosts a positive socialization context where egalitarian knowledge and attitudes towards science can be acquired. Participating teachers value the experience since there are still very few coeducational school interventions focused on young children. Participating families have increased their knowledge of women scientists they barely knew before and believe that these women deserve public appreciation. To conclude, INFACIENCIA has been regarded as a very positive experience both by teachers and families, thus claiming for it to be carried out again.
\end{abstract}

Keywords: sustainable development goals; early childhood education; special education; educational innovation; gender equality

\section{Introduction}

The Sustainable Development Goals set forth a global agenda calling for a sustainable economic, social, and environmental development model [1,2]. This agenda includes 17 Sustainable Development Goals (SDGs), 169 targets, and 232 indicators, focused on people, the planet, prosperity, peace, and partnerships.

Goal 4 is dedicated to ensuring inclusive, equitable, and quality education and promoting lifelong learning opportunities for all. This objective is based on the firm conviction that education is one of the most powerful ways to guarantee sustainable development and social transformation, allowing us to move towards a fairer way of life. Closely related to Goal 4 is Goal 5, dedicated to achieving gender equality and empowering all women and girls. The two objectives, intertwined, are based on the following principles: (1) education is a fundamental right that must pursue the full realization of human potential and promote peaceful coexistence; (2) education is a public good that must be regulated and supported by states; and (3) gender equality is essential to quality education, not only as a matter of human rights, but also because of the need to harness the talent of all our human resources. 
To advance towards high-quality education, which must, necessarily, include gender equality, Goal 4.2 indicates that it is necessary to ensure that all girls and boys have access to care and education services during early childhood, and high-quality education during this stage, with at least one year of Early Childhood Education (ECE) provided by qualified professionals being recommended. This goal is in line with the contributions of Neuroscience [3,4], in which ECE is identified as an ideal stage during which to work on personal identity through the forging of emotional and relational bonds, as well as to design stimulating, creative, and individualized learning environments and experiences that allow young boys and girls to acquire democratic values, while developing competencies to adequately tackle their academic futures [5]. Hence, providing quality care and education during the early years of childhood allows us to impact the development of children's incipient personalities, with its impact being more lasting when interventions are carried out in earlier stages of life [6].

ECE is, indeed, the first cornerstone of the individual's comprehensive development in our educational system. In addition, given that the construction of femininity and masculinity is a collective enterprise, schools constitute an invaluable forum for young girls and boys to develop their personal identities through interaction with adults and peers at the school. The ECE stage is a key phase, then, for the acquisition of gender identity, so educators' coeducational intervention should be intentionally planned and delivered.

Sustainable Development Goals 4 and 5, by means of the principles of quality, gender equality, and intervention in the early stages of childhood, are the cornerstones underpinning the coeducational and innovative program introduced in this paper. It focuses on a study that evaluates a coeducational intervention program to be implemented with Early Childhood and Special Education children. Its aim is to deepen the life and discoveries of poorly recognized female scientists. Thus, the intention is to eradicate the patriarchal, masculinized, and stereotyped nature of science from the very beginning of life, in order to generate a gender inclusive image of science which, in the future, may be seen as a valuable professional field for young girls.

\subsection{Gender Inequality in Science}

The minority presence of women in Science is a phenomenon corroborated by multiple national and international reports [7-11]. For several decades, the feminist research method has been used to highlight the hurdles that women face in terms of access to and promotion and leadership in the scientific sphere [12]. A great number of studies [13,14] point out that sexist stereotypes and a scarcity of prominent female scientists are the key factors dissuading girls from going into science, which they view as a professional area alien to their gender. From the early years (specifically, from the age of 6), girls see themselves as having less intellectual capacity for science than boys [15]. The scientific community adduces four fundamental causes to explain this situation:

1. The prevailing school culture continues to socialize students by transmitting traditional gender stereotypes and values. School culture is a dynamic, contingent, and contextual social construction built within a patriarchal society [16-19] and featuring gender bias because it is permeated by traditional sexist stereotypes and roles [20].

2. Teachers, men and women alike, have little training in the gender issue. In initial teacher training, studies confirm the scant presence of equality-related subjects in curriculums [21]. In continuous training there is also limited demand for training actions on gender due to the issue's invisibility for most teachers, both male and female [22].

3. The curriculum and teaching resources used in ECE barely incorporate the gender perspective. Thus, it is necessary to amend the sexist content found in educational materials, as well as to include guidelines for joint action with families in the development of curriculums to overcome traditional gender stereotypes $[23,24]$.

4. Few role models of female scientists are upheld at ECE services. One of the main biases in school culture is the androcentrism that pervades the scientific content taught in classrooms, as well as 
its transmission in textbooks [25]. One of this androcentrism's characteristics is its omission of the contributions of women scientists in classrooms $[26,27]$.

This study has as its main research question: Is it possible to increase knowledge about important women scientists amongst children aged 3 to 6 ? To this end, it proposes an evaluative study of the coeducational program INFACIENCIA: De las niñas de hoy a las científicas de mañana (INFACIENCIA: From the Girls of Today to the Women Scientists of Tomorrow) (hereinafter, INFACIENCIA), analyzing the opinions and perceptions of the participating teachers and families. The research questions that guides this work have to do mainly with the contribution of this coeducational program to the acquisition of knowledge about women scientists by the entire educational community, and the development by very young students of an inclusive concept of science, one that recognizes female talent and regards science as an engaging career area for girls.

\subsection{INFACIENCIA: A Co-Educational Program to Raise Awareness of Women Scientists amongst Children}

The program being evaluated has spanned two academic years, for eight months-from October to May-each year. This program features an inter-institutional character because the university, the Teacher Training Centre (hereinafter TTC), and the schools have participated. Specifically, university students taking the Teaching the Experimental Sciences course, and ECE and Special Education boys and girls aged 3-6, have participated. It included 20 sessions, which were divided into the following phases:

1. The selection of women scientists, study of their biographies, and the design of activities in ECE and university classrooms.

The selection of a woman scientist in each of the participating ECE and Special Education classrooms, using as a criterion the relationship between the female researcher's discoveries and the topic of the project carried out in the classroom, within the framework of the Project-Based Learning Methodology (hereinafter, PBLM). During the two editions of the program, teachers, together with children and their families, selected 15 women scientists, for example: Rosalind Franklin — "The Human Body" project, Sylvia Earle- "We Discover the Sea" project, María Montessori-“'Sensory Education" project. In the classrooms, an approach to the content was made, and activities were carefully planned (dramatic games, poetry, drawings, experiments, "television news broadcasts", films of the woman scientist's life, stories, riddles, models, etc.).

Meanwhile, the three groups of university students taking the Teaching the Experimental Sciences course, who were enrolled at the Early Childhood Education Teaching degree, guided by their teacher educators, searched for information, organized into teams, on the women scientists selected in the ECE classrooms, synthesized their biographies, and prepared activities aligned to the competences of ECE and Special Education children. The group work was displayed in the university classrooms, and the three best teams per class were selected to implement their projects by visiting the ECE and Special Education classrooms.

2. University students' visit to the ECE and Special Education classrooms.

A previously arranged session was held at each school with the group of both university students and children. First, children showed the university students what they had learned about their female scientist through evidence of their works: theatre exhibitions, drawings, posters, shadow play, pre-conceptual maps, songs, poetry, the reproduction of the DNA chain using putty, analysis of worms' metamorphosis process into butterflies.

The pre-service ECE teachers (university students), meanwhile, carried out with children the activities that they had prepared at university. These included: the simulation of a seismograph, analysis of gorillas in the jungle, re-enacting first aid cures, noise pollution analysis, analyzing insects with a microscope, a sensory book and tactile corridor, an experiment with iodized and non-iodized salt and starch, building an aquarium, cleaning waste from a sea of paper. 


\section{INFACIENCIA Fair.}

In a public space, a forum was held in which the 10 schools involved (children, teachers, and families), the ECE advisors from the TTC, and the teacher educators from the university, participated. Eight stands were set up at each edition, with a life-size woman scientist (a mannequin was used) created together by children, their families, and the teachers. The materials that had been produced by each ECE or Special Education classroom when studying their woman scientist were exhibited. Children, organized into groups, rotated around each stand, observing the work done by their peers at other schools and participating in two activities designed for them to learn more about each woman scientist. This was an opportunity to get to know the life and research achievements of other women scientists and a perfect opportunity for ECE and Special Education children to interact.

4. Evaluation of the experience by everyone involved.

At the end of the experience in each classroom, an assembly was held to assess its strengths, weaknesses, and proposals for improvement, with the aim of applying them when planning for the next edition of INFACIENCIA. Teachers and families were also interviewed, and "drawing-interview" sessions were carried out with children.

\section{Materials and Methods}

\subsection{Participants}

This coeducational program was run in the 2017/18 and 2018/19 academic years, under the auspices of a project funded by the Spanish Foundation for Science and Technology (FECYT) entitled INFACIENCIA. De las niñas de hoy a las científicas de mañana, I y II. Ten public and state-subsidized Early Childhood Education, Primary, and Special Education schools in Córdoba and Seville participated. Five hundred and thirteen ECE and Special Education children participated, together with 80 families, 18 ECE and Special Education teachers, 325 university students, 8 university professors, 2 Ph.D. students, 2 Masters students, and 3 ECE advisors from the TTC in Córdoba. In total, there were 951 participants.

\subsection{Research Questions}

- Is it convenient to carry out scientific divulgation activities in Early Childhood and Special Education?

- Does participation in a coeducational science program in Early Childhood and Special Education contribute to guarantee equality between young girls and boys?

- What lessons are learned after participating in INFACIENCIA, according to teachers and families?

- What are the strengths and weaknesses of the INFACIENCIA program?

\subsection{Methodology and Instruments}

An evaluative research methodology was used, understood as "research that involves a rigorous, controlled and systematic process for collecting and analyzing reliable and valid information to make decisions about an educational program" [28]. This work is driven by an interest in valuing the effectiveness of the INFACIENCIA program, in order to obtain evidence that allows us to guide intervention processes. The evaluation of this program is based on qualitative and ethnography research strategies to give voice to the members of the educational community, using semi-structured interviews with the families and teachers and a "drawing-interview" with children (Figure 1) [29-31]. Due to word-limit restrictions, in this paper we only address the evaluation carried out by teachers and families. 


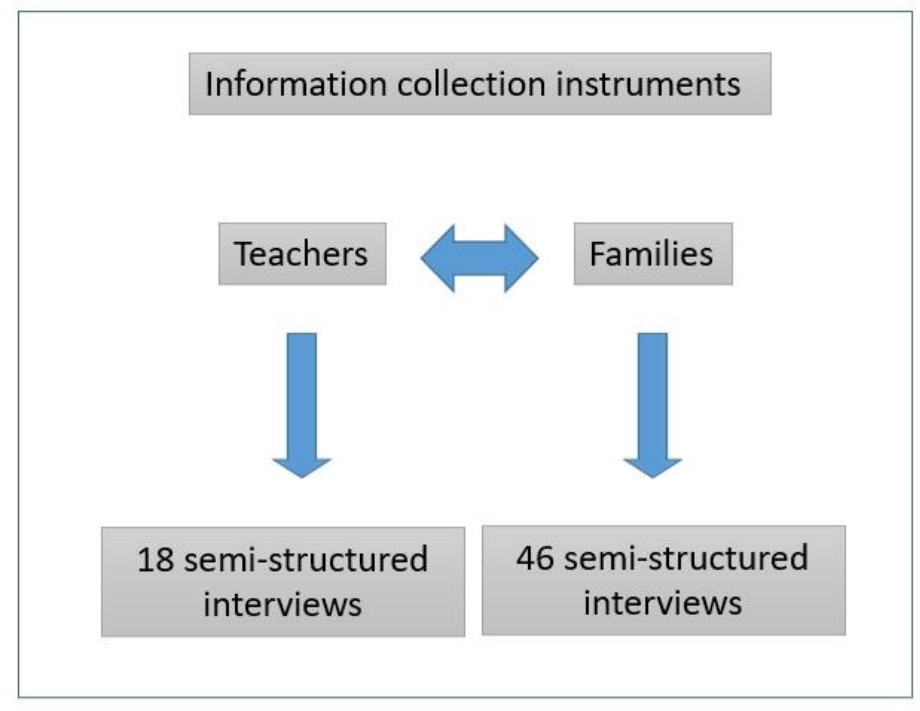

Figure 1. Instruments for information gathering (authors' own).

The script for the interviews with the teachers and families featured the following questions: (1) Do you consider it appropriate to carry out scientific divulgation activities in Early Childhood and Special Education? Why? (2) Do you think it is necessary to begin to highlight, at the ECE or Special Education level, women's roles in and contributions to Science? Why? (3) As an ECE or Special Education teacher/family member, indicate the three most relevant lessons you have learned by participating in INFACIENCIA. (4) What is your level of satisfaction after participating in INFACIENCIA? Would you repeat the experience? Would you recommend this experience to other teachers/family members? (5) Indicate weaknesses and suggestions for future editions. These questions correspond to the exploratory hypotheses adopted for this study.

\subsection{Categorization and Coding}

Once the interviews were audio-recorded and transcribed, following a deductive-inductive process, two types of analysis units were established, some of which are more "macro", the dimensions, which were derived directly from the research questions and the script of questions for the interviews. Each dimension includes several categories, which are more micro units of analysis emerging from the participants' discourse. The categorization process was based on an inter-judge agreement, in which the researchers proposed a provisional hermeneutical matrix, which was agreed to with a representative of both the teachers and the families, to establish it as definitive. Both the dimensions and the categories were analyzed and organized in a relational manner, using the ATLAS.ti statistical program (version 8.4), identifying similarities and discrepancies between the discourse of families and teachers.

The coding process identified each category in such a way that they were mutually exclusive. Initially, the text was classified, following the established dimensions, assigning to each intervention, or fragment of the discourse, a number according to the category to which it belongs, followed by the initial of the group (families-F; teachers-T), and an ordinal number identifying each family/teacher. In this way, and following the classification of the hermeneutical matrix (Table 1), code 3.1.F. 8th corresponds to the discourse articulated by the eighth family member, in relation to the third dimension, referring to lessons learned, and, specifically, to the first category, which includes lessons related to the lives of the women scientists. 
Table 1. Units of analysis obtained from analysis of the teachers' and families' discourse (authors' own).

\begin{tabular}{lll}
\hline \multirow{2}{*}{ Dimensions } & \multicolumn{1}{c}{ Categories } \\
\cline { 2 - 3 } & \multicolumn{1}{c}{ Teachers } & \multicolumn{1}{c}{ Families } \\
\hline 1. Science divulgation in ECE & $\begin{array}{l}\text { 1.1. T. Motivation } \\
\text { 1.2. D. Curiosity }\end{array}$ & $\begin{array}{l}\text { 1.1. F. Useful } \\
\text { 1.2. F. Necessary }\end{array}$ \\
\hline \multirow{2}{*}{ 2. Visibility of women scientists } & $\begin{array}{l}\text { 2.1. T. Knowledge } \\
\text { 2.2. T. References for girls }\end{array}$ & $\begin{array}{l}\text { 2.1. F. Knowledge } \\
\text { 2.2. F. Social justice }\end{array}$ \\
\hline \multirow{3}{*}{ 3. Lessons learned } & 3.1. T. Science in the classroom & 3.1. F. Lives of women scientists \\
& 3.2. T. Working on equality & 3.2. F. Children's competences \\
& 3.3. T. Connections between schools & 3.3. F. Collaboration with the school \\
\hline \multirow{2}{*}{ 4. Satisfaction level } & 4.1. T. Positive & 4.2. F. Highly positive \\
\hline \multirow{3}{*}{ 5. Weaknesses } & 4.2. T. Colleague's invitation & \\
& 5.1. T. Temporal distribution & 5.1. F. Temporal distribution \\
& 5.2. T. Student participation & 5.2. F. Excessive demand \\
\hline 6. Suggestions & INFACIENCIA Fair & \\
\hline
\end{tabular}

\subsection{Data Analysis Techniques}

As we have gathered textual data, drawn from the transcription of the teachers' and families' narrations, the discourse analysis technique was used [32]. Interpretation of the narrative discourse was based on grounded theory. The categories were then encoded, synthesized, and related by means of a hermeneutical matrix, to generate general knowledge based on particular sets of discourse [33].

\subsection{Research Quality and Ethics}

The quality of this research is aligned to the criteria of the qualitative paradigm [34], which are transferability, consistency, and intersubjectivity. Besides, the ethical criteria of research referring to "neutrality, social validity, and informed consent" were respected [35].

\section{Results}

Once transcribed and encoded, the analysis of the discourse of the teachers and the families allowed for the development of this hermeneutical matrix (Table 1).

The results are organized following the research questions, integrating into each of them the data gathered from the teachers and families.

1. Experience of scientific divulgation in early childhood education

All the interviewed teachers and families agreed on including scientific divulgation activities in the second stage of Early Childhood Education. The reasons explaining this positive attitude include, among the teachers, the engaging nature of science activities for young boys and girls.

"I do believe that it is important to work on science ... they love it ... And it also motivates them a lot" (1.1.T. 12th).

They advocate for seeking to cultivate scientific literacy in the classroom from an early age and emphasize that the most important thing is not to approach science as part of the curriculum, but rather to reflect on how science can be introduced in the early years. They believe that the cognitive capacities during childhood, and children's particular way of learning at these ages, merit the use of observation, exploration, and experimentation as basic principles to access scientific knowledge. They subscribe, at least at a theoretical level, to the socio-constructivist theory of learning, which they introduce in their classrooms through the methodology of Project-Based Learning (PBL). 
This methodology is based on a research-based approach to learning, according to which teachers do not transmit knowledge, but rather explore the children's previous ideas and questions in order to guide them while autonomously constructing their own knowledge. This, then, becomes knowledge that helps them to function better in their lives' settings and that arises from small daily actions; then it is rooted in concretion and action, and is developed day by day, as children's curiosity acts as an inexhaustible source of learning. They use children's questions, regarding their social and physical environment, and their capacity for surprise as the keys with which to approach learning science in ECE classrooms. A useful, accessible science that helps them to shift from magical thinking to increasingly systematic and objective knowledge of reality.

"I think it is very important to do science activities, but always in a meaningful way, related to the topic of the projects ... not just because now it's time for science" (1.1.T. 4th).

Families, meanwhile, believe that scientific divulgation and, specifically, the INFACIENCIA program, is a necessary educational initiative. In their opinion, schools do not work on gender equality in education enough. They express that a focus on equality is clearly limited to specific events and days. Among families there is disagreement between those who believe that school should be an environment for the transmission of democratic values and attitudes, and those who think that at schools, above all, curricular content should be learned, as in their view it is families that should be responsible for instilling in their children the values and "ideology" they deem most appropriate.

"It seems to me everything can't be done at school ... Equality, the environment, solidarity, peace ... Schools must focus on giving children the foundations of knowledge... The rest should be done at home, in the way each family considers better" (1.1.F. 23rd).

Despite this different approach, all the families regard the introduction of scientific divulgation activities in Early Childhood Education as necessary. They explain that, in the social imagination, science is portrayed as an activity that is far removed from citizens, conceived of as a body of knowledge suitable only for people who are very specialized in the field and who dedicate their professional lives to research. It is not perceived as an activity that is part of daily life, and that permeates everyday actions. Thus, they believe that it is necessary to demystify the concept of science right from childhood, presenting it as an area accessible to everybody, this being essential to bolster social well-being. These scientific divulgation activities, in the opinions of families, contribute to the democratization of science, because, through adequate didactic mediation, they integrate it in accord with the skills of children, taking advantage of their innate curiosity.

"I think that these activities with children are great, as they gradually develop an interest in science from the beginning. ... and they don't see it as something that only an elite of ultra-gifted people dedicate themselves to" (1.2.F. 28th).

\section{Raising awareness of women scientists}

The second dimension involves the need to show the scientific potential of women among young boys and girls. Both the teachers and the families agree that INFACIENCIA offers children the opportunity to learn about overlooked women whose contributions have been highly valuable to humanity. Above all, it generates a learning platform for teachers and families, who acknowledge that they have limited knowledge of women's scientific discoveries. Learning about, together with student teachers, the lives of scientists like Mary Walton, Vera Rubin, and María Sibylla has allowed them not only to understand their enormous talent, but also to appreciate the difficulties and limitations that these women had to overcome, as science was all but off limits to them, as they were women trespassing into an exclusively male domain. They have learned to appreciate, in addition to the cognitive potential of these women, their defiant and resilient attitudes as they challenged a gender-based division of labor imposed by the socially established patriarchal order. 
Most families stressed the need to do social justice to women who have been omitted from textbooks and the official educational system's curriculum. Being involved in this coeducational program has allowed both teachers and families, as adults, to reflect on the deficiencies of their formal educational system and how it affected them. INFACIENCIA has fostered enhanced awareness of the change that schools are undergoing, with participants experiencing first-hand how much can be done at schools to change the way future generations see the world. They indicate that what is not known does not exist, so they are in favor of schools evolving in keeping with social shifts. In this regard, some families believe that ECE should incorporate social changes, while others hold that the function of schools is to promote the values of progress and egalitarian democratic citizenship, proactively acting as a "spearhead" of necessary social change.

"It seems to me that it is a question of social justice... The life and work of great women we did not even know existed should be dusted off and brought to light... History has not been fair to them" (2.2.F. 45th).

While families focus on the need to do social justice on behalf of women scientists, teachers emphasize the need to offer female scientific role models that allow young boys and girls to understand that science is inclusive, accommodating both women and men. In this regard, there are discrepancies between the teachers' opinions. Most believe that there is still gender inequality affecting social and family life, and that this inequality of opportunities is reflected in the research sphere, which is, after all, a social subsystem governed by society's dominant stereotypes, roles, and values. This group believes that one of the fundamental potentialities of INFACIENCIA is, precisely, to offer female role models for girls, from an early age, so that they can have mental representations of women who have successfully dedicated their lives to science. They believe that the motto "if they were able to, you can too" is a very powerful lesson, based on the principle of exemplariness, which must be applied at the stage when the foundations of incipient personal identities are being laid. However, a third of the teachers interviewed believe that real equality has already been achieved, and that in the field of research women have the same opportunities, or at least in science supported with public funds. They still believe, however, that it is beneficial to study the lives of women scientists to learn about some interesting discoveries that have not been made public. This is a kind of historical debt that, in their opinion, is not applicable to current science, in which there is no longer inequality in women's access to the field or in their promotion on equal footing with men.

"I find it very important that our girls learn about these women scientists... They should know that they can also do science ... and dream that, when they grow up, they can be whatever they want, not whatever their parents tell them or society imposes on them" (2.2.T. 17th).

\section{Lessons learned from INFACIENCIA}

The lesson learned most cited by the interviewed teachers was the possibility of teaching science in children's classrooms in a fun way by exploring the lives of exciting and unsung women. They point out that a great amount of creativity is required to pedagogically adapt and convey the experiments and findings of women scientists who have investigated subjects like black holes, DNA, and noise pollution, to children, taking into account their capacities. These are abstract and complex issues far removed from children's daily lives, so they must be adapted a lot to make them understandable and meaningful for children. They explain that, even though the discoveries of the women scientists chosen were related to the topic of the project being done in class, an effort had to be made to spark their interest in these female scientists, who unexpectedly "landed" in the classroom. Their pedagogical audacity generated enthusiasm in the children, in most cases.

"I really racked my brain to 'insert' Maria Sibylla into the spring project ... It turns out that a dead moth I found in the classroom made my work sooo much easier ... Our entomologist dedicated herself to painting and researching butterflies" (3.1.T. 9th). 
The second lesson learned cited by the teachers was the opportunity to work on gender equality in education in a novel way. They indicate that the reading of coeducational stories, the non-sexist games corner, the celebration of International Women's Day, non-sexist professions, etc., are activities that they do regularly, but this way of learning about talented women overlooked in the scientific arena has opened up a new "window" for them to work on gender equality in a more contextualized way than in the sometimes repetitive initiatives drawn from the schools' equality official programs. In fact, some teachers reported that there has been a "viral" effect at their schools, and that on March 8 , a woman scientist was studied in all the classes.

A third important lesson for the teachers was the possibility of instituting collaboration networks with other schools that also participate in INFACIENCIA. Collaborating with other colleagues, sharing resources, posing questions and concerns, etc., generates an excellent opportunity for professional growth, bolstering motivation and shared learning. Particularly relevant was interaction with Special Education colleagues, thus INFACIENCIA becoming an opportunity to share activities such as the final fair, at which there were moments when ECE and Special Education children spent time together.

\section{"I learned a lot, and I even got excited when I saw the kids telling the Special Education kids about Gabriella Morreale" (3.3.T. 15th).}

The families, meanwhile, stated that the three fundamental things they took away from INFACIENCIA were: what they and their children learned about the woman scientist studied, an appreciation of children's enormous learning capacity, and also of the benefits of family-school collaboration. The families expressed their scarce knowledge, in most cases, of the woman scientist studied, and, therefore, appreciated the opportunity that this program gave them; above all, because it was not an individual experience, but rather a joint one, along with their child, as they had to cooperate in the search for information and in the development of resources. They experienced the complexity of helping children learn, while being impressed by their enormous potential for learning and unrelenting curiosity. They also expressed that this type of project, which requires a great deal of involvement by families, makes it difficult to balance their contribution to the school initiatives with their work responsibilities and the lifestyles they lead. Some families state that family involvement is essential to children's learning, but that this involvement must be regulated so that it does not become a "race to see who produces the most spectacular work, on which the child has not done anything" (3.3.F. 47th).

4. Level of satisfaction, weaknesses, and suggestions

The last three dimensions were grouped into one, due to their level of interrelation. Both the teachers and the families reported good levels of satisfaction with their participation in the INFACIENCIA program, with the families' evaluation being higher (very positive) than that of the teachers (positive). In the case of teachers, the main reasons for their positive assessments were the opportunities that it offered them to work on an unusual topic in the classroom, the chance to work on coeducation and science with children, as well as the inter-institutional work with other schools, the Teacher Training Centre, and the university. Families, meanwhile, expressed very high levels of satisfaction thanks to the opportunity to work actively with their children, the motivation that was generated, and because children, from a young age, were enabled to adopt critical positions in facing the injustice related to the inequality between women and men in the scientific sphere.

"What I liked the most was seeing our children criticizing the segregation of women scientists ...

Their outrage at this injustice was surprising" (4.2.F. 41st).

All the interviewed teachers would recommend this coeducational experience to colleagues, endorsing its implementation at a vertical level in schools' different stages to give it continuity and so that its impact is augmented. 
"Yes, I would recommend this program to other colleagues. Above all, to the administration, which should propose it for the entire school" (4.2.T. 13th).

Identified as the most important weakness, pointed out by both teachers and families, was the program's spatial-temporal organization; harmonizing the dates to adjust them to the needs of the professionals who intervene at the different institutions was recommended.

The families suggested that, although it is true that one of the program's strengths is families' involvement and co-responsibility for the learning process of their children, this can also be a huge weakness if it is not properly channeled and regulated. A majority also stated that the guidelines that families must follow in their intervention must be clarified; that is, what they should do, how, and when. In the absence of guidelines, each family sets its own pace, and even its own level of demands.

"I was amazed when I saw the model ... I could never do that ... I was stressed when I saw it because I felt like I couldn't help my daughter like the other parents did" (6.2.F. 35th).

Some families suggest that critical reflection should be carried out in relation to the type of help that should be offered, because there is a great diversity of families in each classroom, and there are families who have more time, more resources, and greater abilities or skills. These differences cannot be projected in the classroom as inequalities having a negative impact on children. It is necessary to create a climate of cooperation between families so that the children understand that families' contributions are a common good from which everyone benefits rather than a competition to personally "show off".

\section{Discussion and Conclusions}

We discuss the findings according to the research questions established. The first one is: Is it convenient to carry out scientific divulgation activities in Early Childhood and Special Education? There is abundant literature [36,37] demonstrating the value of working on scientific literacy from an early age, due to the greater receptivity of young children. These children are at a critical juncture [38] of maximum plasticity in their learning, continuous exploration of their physical and social ecosystem, and the development of incipient personal identities [39]. Therefore, the INFACIENCIA program is congruent with other experiences and programs implemented in various contexts, which propose various experiments adapted to children's capacities [40]. It is corroborated, in accordance with other contributions, that learning science through scientific practices in ECE and Special Education classroom allows children to improve their understanding of the settings in which they live, test their ideas, develop positive attitudes towards science, and achieve a solid foundation to understand scientific and more abstract concepts at higher educational levels [41]. This experience of teaching science in Early Childhood and Special Education allows us to state that a pedagogy of science is necessary, understood as a transversal axis permeating daily activity in ECE and Special Education classrooms, as it constitutes a way to acquire new knowledge through inquiry, modelling, observation, exploration, and the verification of phenomena [42]. The socio-constructivist theory [43] and the deep approach to learning [44], in agreement with our findings, proved to be two means to promote children's scientific literacy, overcoming superficial models that identify learning science with the sporadic marking of relevant anniversaries.

The second research question is: Does participation in a coeducational science program in Early Childhood and Special Education contribute to guarantee equality between young girls and boys? The results of this study reveal teachers' and families' general ignorance of the lives and contributions of important female scientists, with this data being consistent with that found in other studies $[45,46]$. The scarcity of female role models in boys' and girls' social ecosystem (school and family) deprives them of both formal and informal knowledge of the past and present contributions of women to science, perpetuating an androcentric image of the field, which is still viewed primarily as a male domain. This study suggests that learning about female scientists not only impacts ECE and Special Education children, but also extends to families and teachers, generating a global ecosystem of socialization 
favoring the acquisition of more egalitarian scientific knowledge and attitudes. This sociocultural model for the deconstruction of a sexist vision of science coincides with a model that includes a broad range of social influences (sexist stereotypes, biases and roles, family attitudes and expectations), as well as female educational models as elements affecting girls' future career choices [47].

It should be borne in mind that, although many efforts have been made in recent decades to encourage girls' vocations in STEM (Science, Technology, Engineering, and Maths), in the United States, for example [48], what is called the "gender equality paradox" [47] continues to occur; that is, the controversy that ensues upon verifying that countries with generally high levels of gender equality actually have some of the largest STEM gaps in secondary and post-secondary education. These are countries that include the gender perspective in their compulsory schooling curricula (primary and secondary), but, with rare exceptions, do not raise awareness of the contributions of women scientists in the earliest stages of the school system, i.e., ECE. This study reveals that it is possible to develop a conception of inclusive science from early ages (3-6), introducing it in the Early Childhood and Special Education curriculum in a transversal and comprehensive way so that it impacts the entire educational community (students, families, and teachers).

The third research question refers to the lessons learned from participating in this coeducational program. The teachers mention their own learning and the professional challenge posed by having to didactically manage the complexity of some scientific experiences undertaken in the classroom and children's abilities, in line with other findings [49-51]. Another issue the teachers point to is the opportunity to participate in a novel coeducation strategy in ECE and Special Education by addressing the presence of women in science, because, although there are numerous resources on women and science already on the market, both in print (Good Night Stories For Rebel Girls, Women in Science, and My First Book About Women) and digital format (Women in Science Didactic Series, Invisible Women Scientists, Women Geniuses Around the World, Science Is a Girls' Thing, and Women and Scientific Activity), there are very few school intervention programs on coeducation in science adapted to the ECE stage and Special Education. In this regard, this program provides a tool that can serve as a reference for its transferability to similar educational contexts.

Another takeaway of teachers participating in INFACIENCIA is how they were professionally stimulated by interacting with other professionals at various institutions (TTCs, other schools and universities). The collaborative learning enjoyed by interacting in a professional network yielded results similar to those reported by previous studies $[52,53]$.

Most of the families interviewed underscored that the coeducational program increased their knowledge of women scientists, of whom they were ignorant and who deserve acts of recognition and social justice. However, controversy arises in a minority of families who view the introduction of egalitarian values in ECE classrooms as a form of "ideological indoctrination", indicating that this transmission of values should be carried out at home. This view clashes with current legislation, as well as with extensive literature demonstrating the impossibility of neutral, value-free education, as the influence that teaching professionals have on children when interacting with them is inevitable [54-56]. The aforementioned families' posture questions the very cornerstones of Early Childhood Education, considered as a social, political, and ethical practice for the learning of democracy, as posited in other works $[57,58]$ and in Spain's current educational legislation.

Another relevant aspect that the study points to is the balance families need to be able to strike between their desire to participate in the educational processes of their children and the need to juggle this with their family responsibilities. As in other studies [59,60], an alternative form of collaboration is needed to achieve sustainable family-school partnerships.

To conclude, it can be stated that the levels of satisfaction with INFACIENCIA expressed by the interviewed teachers and families were high, with them endorsing the continuity of the program while recommending the reformulation of some of its organizational aspects in order to harmonize the speeds and time demands of the different participating institutions. 


\section{Limitations and Future Lines of Research}

The results obtained, upon evaluating the coeducational program on science in ECE and Special Education, should be interpreted with caution because they are limited to a local context, and because they represent a first step in a promising line of research that should investigate, in the future, the transferability of this experience to other contexts. It is necessary to guarantee the continuity of the program, in order to assess its impact in the medium and long term (for example, at the end of the compulsory schooling). In addition, longitudinal studies are required to ascertain whether the boys and girls who participate in this educational intervention possess more knowledge about women scientists, with the aim of gradually developing an inclusive conception of science from the earliest ages.

Author Contributions: Conceptualization, R.M.-S.; Data curation, M.E.G.-A. and M.M.-M.; Formal analysis, M.A.O.-G., M.E.G.-A. and J.R.-C.; Funding acquisition, R.M.-S.; Investigation, M.E.G.-A. and M.A.O.-G.; Methodology, M.E.G.-A. and J.R.-C.; Project administration, R.M.-S., M.E.G.-A. and M.A.O.-G.; Software, M.M.-M.; Supervision, R.M.-S.; Visualization, J.R.-C. and M.M.-M.; Writing-original draft, R.M.-S.; Writing-review and editing, J.R.-C. and M.M.-M. All authors have read and agreed to the published version of the manuscript.

Funding: Reference FCT-17-11977. The Spanish Foundation for Science and Technology (FECYT). Ministry of Science and Innovation. Government of Spain.

Conflicts of Interest: The authors declare no conflict of interest.

\section{References}

1. Girón, A. Objetivos del Desarrollo Sostenible y la Agenda 2030: Frente a las Políticas Públicas y los Cambios de Gobierno en América Latina. Probl. Desarro. 2016, 47, 3-8. Available online: http://www.scielo.org.mx/ scielo.php?script=sci_arttext\&pid=S0301-70362016000300003 (accessed on 14 February 2020).

2. Alonso-Naveiro, M. El modelo "sostenible" heredado por los instrumentos de sostenibilidad. Cuad. Investig. Urbanística 2018, 118, 5-67. [CrossRef]

3. Mérida-Serrano, R.; González-Alfaya, M.E.; Olivares-García, M.A. Networking and professional development among teachers of early childhood education. Foro Educ. 2017, 15, 243-256. [CrossRef]

4. Mora, F. El cerebro solo aprende si hay emoción. Educación 3.0, 5 September 2018. Available online: https:/www.educaciontrespuntocero.com/entrevistas/francisco-mora-el-cerebro-soloaprende-si-hay-emocion/33224.html(accessed on 15 February 2020).

5. Lightfoot, S.; Frost, D. The professional identity of early years educators in England: Implications for a transformative approach to continuing professional development. Prof. Dev. Educ. 2015, 41, 401-418. [CrossRef]

6. Johansson, E.; Einarsdottir, J. (Eds.) Values in Early Childhood Education: Citizenship for Tomorrow; Routledge-EECERA: London, UK, 2017.

7. Rodríguez, A.P. Científicas en Cifras. Estadísticas e Indicadores de la (Des)igualdad de Género en la Formación y Profesión Científica; Unidad de Mujeres y Ciencia, Ministerio de Ciencia, Innovación y Universidades: Madrid, Spain, 2017; Available online: https://www.ciencia.gob.es/stfls/MICINN/Ministerio/FICHEROS/ UMYC/Cientificas_cifras_2017.pdf (accessed on 22 February 2020).

8. Observatorio Mujeres, Ciencia e Innovación. In Informe Mujeres e Innovación; Ministerio de Ciencia e Innovación: Madrid, Spain, 2020; Available online: http://code.intef.es/informe-mujeres-e-innovacion-2020malas-cifras-pero-con-brotes-verdes/ (accessed on 22 February 2020).

9. European Commission, Directorate-General for Research and Innovation. She Figures 2018; Publications Office of the European Union: Luxembourg, 2019. [CrossRef]

10. Society of Spanish Researchers in the United Kingdom. Percepciones Que Crean Barreras. Informe CERU-COTEC Sobre Igualdad de Género en Ciencia; Society of Spanish Researchers in the United Kingdom: London, UK, 2019; Available online: https://cotec.es/media/20190919Cotec_Encuesta_SRUK_CERU.pdf (accessed on 9 November 2020).

11. European Commission. Report on Equality Between Women and Men in the EU; Publications Office of the European Union: Luxembourg, 2019. [CrossRef]

12. Campbell, S.; Smith, K.; Alexander, K. Spaces for Gender Equity in Australian Early Childhood Education in/Between Discourses of Human Capital and Feminism. Australas. J. Early Child. 2017, 4, 54-62. [CrossRef] 
13. Colás, P.; Villaciervos, P. La interiorización de los estereotipos de género en jóvenes y adoslescentes. Rev. Investig. Educ. RIE 2007, 25, 35-58. Available online: https://revistas.um.es/rie/article/view/96421/92631 (accessed on 15 February 2020).

14. Maphanga, N.P.; Morojele, P.J.; Motsa, N.D. Gender dynamics in children's cross-sex relationships: A case from a south african farm school. Gend. Behav. 2018, 16, 11854-11869.

15. Bian, L.; Leslie, S.; Cimpian, A. Gender stereotypes about intellectual ability emerge early and influence children's interests. Science 2017, 355, 389-391. [CrossRef]

16. Apple, M. The struggle for democracy in critical education. Rev. e-Curric. 2017, 15, 894-926. [CrossRef]

17. Bauman, Z.; Leoncini, T. La Generación Líquida: Transformaciones en la 3.0; Paidós: Barcelona, Spain, 2018.

18. Pérez, A.I. Ser docente en tiempos de incertidumbre y complejidad. Márgenes 2019, 3-17. [CrossRef]

19. Pérez, A.I.; Nogueroles, M.; Méndez, A. Una educación feminista para transformar el mundo. Rev. Int. Educ. Justicia Soc. RIEJS 2017, 6, 5-10. [CrossRef]

20. Korthagen, F.A.J.; Nuijten, E.E. Core reflection: Nurturing the human potential in students and teachers. In International Handbook of Holistic Education; Miller, J.P., Nigh, K., Binder, M.J., Novak, B., Crowell, S., Eds.; Routledge: New York, NY, USA, 2019; pp. 89-99. Available online: https://korthagen.nl/en/wp-content/uploads/2019/06/Chapter-on-Core-Reflection-inInternational-Handbook-Holistic-Education.pdf (accessed on 9 November 2020).

21. Aguilar, C. Igualdad, género y diversidad sexual en la Formación Inicial de Maestro/a en la Universidad Jaume I UJI. Temas Educ. 2015, 21, 77-95.

22. Anguita, R. El reto de la formación del profesorado para la igualdad. Rev. Electrón. Interuniv. Form. Profr. 2011, 14, 43-51.

23. Azorín, C.M. Actitudes hacia la igualdad de género en una muestra de estudiantes de Murcia. Rev. Complut. Educ. 2017, 28, 45-60. [CrossRef]

24. García, E.; Rodríguez, F.J.; Bringas, C.; López, J.; Paíno, S.; Rodríguez, L. Development of the Gender Role Attitudes Scale (GRAS) amongst Young Spanish people. Int. J. Clin. Health Psychol. 2015, 15, 61-68. [CrossRef]

25. Sánchez Bello, A. El androcentrismo científico: El obstáculo para la igualdad de género en la escuela actual. Educar 2002, 29, 91-102. [CrossRef]

26. García, S.; Pérez, E. Las 'Mentiras' Científicas Sobre las Mujeres; Catarata: Madrid, Spain, 2017.

27. Solís-Espallargas, C. Inclusión del Enfoque de Género en la Enseñanza de las Ciencias Mediante el Estudio de Biografías de Mujeres Científicas. Rev. Eureka Enseñ. Divulg. Cienc. 2018, 15, 3602. [CrossRef]

28. Tejedor, J. El diseño y los diseños en la evaluación de programas. Rev. Investig. Educ. 2000, 18, 319-339. Available online: https://revistas.um.es/rie/article/view/121021 (accessed on 3 March 2020).

29. Eldén, S. Inviting the messy: Drawing methods and 'children's voices'. Childhood 2013, 20, 66-81. [CrossRef]

30. Nelly, D.D. Uncovering the History of Children's Drawing and Art; Greenwood Publishing Group: Westport, CT, USA, 2004.

31. Rodríguez-Carrillo, J.; Mérida-Serrano, R.; González-Alfaya, M.E. 'A teacher's hug can make you feel better': Listening to U.S. children's voices on high-quality early childhood teaching. Eur. Early Child. Educ. Res. J. 2020, 28, 504-518. [CrossRef]

32. Macartney, B.; Ord, K.; Robinson, L. Three Examples of Using Discourse Analysis in Early Childhood Research. N. Z. Res. Early Child. Educ. 2008, 11, 137-148. Available online: https://search.informit.com.au/ documentSummary; dn=300580813360313;res=IELHSS (accessed on 4 March 2020).

33. Liebenberg, L.; Didkowsky, N.; Ungar, M. Analysing image-based data using grounded theory: The Negotiating Resilience Project. Vis. Stud. 2012, 27, 59-74. [CrossRef]

34. Sandín, P. Criterios de validez en la investigación cualitativa: De la objetividad a la solidaridad. Rev. Investig. Educ. 2000, 18, 223-242. Available online: https://revistas.um.es/rie/article/view/121561 (accessed on 4 March 2020).

35. González, M. Aspectos éticos de la investigación cualitativa. Rev. Iberoam. Educ. 2002, 29, 85-103.

36. Cantó, J.; De Pro, A.; Solbes, J. ¿Qué ciencias se enseñan y cómo se hace en las aulas de educación infantil? La visión de los maestros en formación inicial. Enseñ. Cienc. 2016, 34, 25-50. [CrossRef]

37. López, M.A.; Gil, M.; Verde, A.; Vallés, C. Análisis de una propuesta de formación científica en el grado de Maestro de EI. In Proceedings of the XXV Encuentros de Didáctica de las Ciencias Experimentales, Santiago de Compostela, Spain, 5-7 September 2012; Domínguez-Castiñeiras, J.M., Ed.; Servicio de Publicaciones Universitario: Santiago de Compostela, Spain, 2012; pp. 1141-1148. Available online: http://apice-dce.com/wp-content/uploads/2018/08/XXV-EDCE.pdf (accessed on 7 March 2020). 
38. Ferradás, L.; Zabalza, M.A. Júlia Oliveira Formosinho. Poniendo en valor la Pedagogía de la infancia. Rev. Latinoam. Educ. Infant. RELAdEI 2018, 1, 207-228. Available online: https://revistas.usc.gal/index.php/ reladei/article/view/4660 (accessed on 7 March 2020).

39. Formosinho, J.; Peeters, J. Understanding Pedagogic Documentation in Early Childhood Education. Revealing and Reflecting on High. Quality Learning and Teaching; Routledge: London, UK, 2019.

40. Lozano, O.R.; Solbes, J. 85 Experimentos de Física Cotidiana; Graó: Barcelona, Spain, 2014.

41. Kuhn, D.; Pearsall, S. Developmental origins of scientific thinking. J. Cogn. Dev. 2000, 1, 113-129. [CrossRef]

42. Mosquera, I.; Puig, B.; Blanco, P. Las prácticas científicas en infantil. Una aproximación al análisis del currículum y planes de formación del profesorado de Galicia. Enseñ. Cienc. 2018, 36, 7-23. [CrossRef]

43. Metz, K.E. Children's understanding of scientific inquiry: Their conceptualization of uncertainty in investigations of their own design. Cogn. Instr. 2004, 22, 219-290. [CrossRef]

44. San Fabián, J.L.; Belver, J.L.; Álvarez, C. ¿Nuevas Estrategias y Enfoques de aprendizaje en el contexto del Espacio Europeo de Educación Superior? Red Univ. 2014, 12, 249-280. [CrossRef]

45. Bandura, A.; Barbaranelli, C.; Caprara, G.; Pastorelli, C. Self-efficacy Beliefs as Shapers of Children's Aspirations and Career Trajectories. Child. Dev. 2001, 72, 187-206. [CrossRef] [PubMed]

46. Martínez, M.; Villuendas, M.D. Las mujeres en la formación superior elección de carrera versus estereotipos de género y neosexismos. Cuest. Género 2006, 1, 87-112. [CrossRef]

47. Stoet, G.; Geary, D.C. The Gender-Equality Paradox in Science, Technology, Engineering, and Mathematics Education. Psychol. Sci. 2018, 29. [CrossRef] [PubMed]

48. National Science Foundation. Women, Minorities, and Persons with Disabilities in Science and Engineering: 2017; National Center for Science and Engineering Statistics: Arlington, VA, USA, 2017.

49. Guardia, M.J. La coeducación en Infantil. Innov. Exp. Educ. 2009, 16, 1-9.

50. Martín, M.J. Género y formación del profesorado. Andal. Educ. 2007, 64, 31-33.

51. Simón, M.E. Guía Para la Buena Coeducación de Niñas y Niños; Dirección General de la Mujer del Gobierno de Cantabria, Consejería de Empleo y Bienestar Social: Cantabria, Spain, 2007.

52. Mérida-Serrano, R.; González-Alfaya, M.E.; Olivares-García, M.A. Adquisición de competencias profesionales del alumnado de Magisterio de Educación Infantil a través de una red de colaboración escuela-universidad. Rev. Investig. Educ. 2011, 9, 184-199.

53. Mérida-Serrano, R.; González-Alfaya, M.E.; Olivares-García, M.A. Redes de aprendizaje escuelas infantiles-universidad. Evaluación de una experiencia de innovación. Cult. Educ. 2012, 24, 95-110. [CrossRef]

54. Ärlemalm-Hagsér, E. Gender choreography and micro-structures-early childhood professionals' understanding of gender roles and gender patterns in outdoor play and learning. Eur. Early Child. Educ. Res. J. 2010, 18, 515-525. [CrossRef]

55. Burusic, J.; Babarovic, T.; Seric, M. Differences in Elementary School Achievement between Girls and Boys: Does the Teacher's Gender Play a Role? Eur. J. Psychol. Educ. 2012, 27, 523-538. [CrossRef]

56. Wingrave, M. Perceptions of gender in early years. Gend. Educ. 2018, 30, 587-606. [CrossRef]

57. Clark, A. Ways of seeing: Using the Mosaic approach to listen to young children's persepctives. In Beyond Listening: Children's Perspectives on Early Childhood Service; Clark, A., Kjørholt, A.T., Moss, P., Eds.; Policy Press: Bristol, UK, 2005; pp. 29-50.

58. Moss, P. Bringing politics into the nursery. Early childhood education as a democractic practice. Eur. Early Child. Educ. Res. J. 2007, 15, 5-20. [CrossRef]

59. Minke, K.M.; Anderson, K.J. Family-School Collaboration and Positive Behavior Support. J. Posit. Behav. Interv. 2005, 7, 181-185. [CrossRef]

60. Tett, L.; Macleod, G. Enacting home-school partnerships: The roles of headteachers, family-learning practitioners and parents. Camb. J. Educ. 2020, 50, 451-468. [CrossRef]

Publisher's Note: MDPI stays neutral with regard to jurisdictional claims in published maps and institutional affiliations. 